\title{
Influence of Macroalgal Cover on Coral Colony Growth Rates on Fringing Reefs of Discovery Bay, Jamaica: A Letter Report
}

\author{
M.J.C. Crabbe*
}

\author{
Luton Institute for Research in the Applied Natural Sciences, Faculty of Creative Arts, Technologies \& Science, \\ University of Bedfordshire, Luton, Bedfordshire, LU1 3JU, UK
}

\begin{abstract}
In this study I investigated the hypothesis that alterations in macroalgal cover significantly influenced the growth rates of coral colonies on the fringing reefs of Discovery Bay, Jamaica. For colonies of Montastrea annularis, Porites astreoides, and Sidastrea siderea, radial growth rates were significantly $(\mathrm{p}<0.02)$ higher at Dairy Bull (where Diadema antillarum had removed macroalgal cover) than at either M1 or Rio Bueno (where there was c. 80\% macroalgal cover). For colonies of Colpophyllia natans and Montastrea fankseii, radial growth rates were significantly $(\mathrm{p}<0.02)$ higher at Dairy Bull than at Rio Bueno. It has been suggested that macroalgal shading as well as contact is a significant inhibitor of coral growth, and our results are in accord with that hypothesis. These studies suggest that marine park managers should foster macroalgal predation wherever possible, in order to limit the irreversible decline of coral reefs.
\end{abstract}

\section{INTRODUCTION}

The growth and subsistence of coral depends on a number of requirements: temperature, irradiance, calcium carbonate saturation, turbidity, sedimentation, salinity, $\mathrm{pH}$, and nutrients. These variables influence the physiological processes of photosynthesis and calcification as well as coral survival $[1,2]$. Ecosystem thresholds have been modelled to identify targets for reef restoration [3], and it appears that grazing, particularly by scarids (parrotfish), but also by urchins, is critical to reef resilience and restoration in the face of multiple stressors, including hurricanes $[3,4]$. Macroalgal competition has been shown to reduce the survivorship and growth of corals in forereefs in Roatan, Honduras [5] and in Florida [6]. In this study I investigated the hypothesis that alterations in macroalgal cover significantly influenced the growth rates of coral colonies on the fringing reefs of Discovery Bay, Jamaica.

\section{METHODS}

The study was undertaken from between July 2001 to September 2004, using techniques identical to those described previously [7-9]. The five study sites (Rio Bueno, M1, Columbus Park, Dairy Bull and Pear Tree Bottom) were on the fringing reefs around Discovery Bay [8] as shown in Fig. (1). At each of the five sites, three haphazardly allocated transects, each $12 \mathrm{~m}$ long and separated by at least $5 \mathrm{~m}$, were laid at $8.5 \mathrm{~m}$ depth. Corals at M1, Dairy Bull and Rio Bueno were photographed, subjected to image analysis using the Image Tool software obtained from the University of Texas Health Science Centre, San Antonio, Texas, and physically measured using measuring tapes as described previously [8, 9]. Fish sizes were determined by visual inspection, and by video as described previously [10], where 4 x 4 x 4 m 'boxes' were videod for $5 \mathrm{~min}$ each, at Rio Bueno, Diary Bull, M1, Pear Tree Bottom, and Columbus Park. Urchin

*Address correspondence to this author at the Luton Institute for Research in the Applied Natural Sciences, Faculty of Creative Arts, Technologies \& Science, University of Bedfordshire, Luton, Bedfordshire, LU1 3JU, UK; E-mail: James.Crabbe@beds.ac.uk
(Diadema antillarum) counts at Rio Bueno, Diary Bull, M1, Pear Tree Bottom, and Columbus Park were by inspection. One or two-factor ANOVA was used to compare data among sites; +/- error values in Figs. (3-5) represent standard deviations of the data.

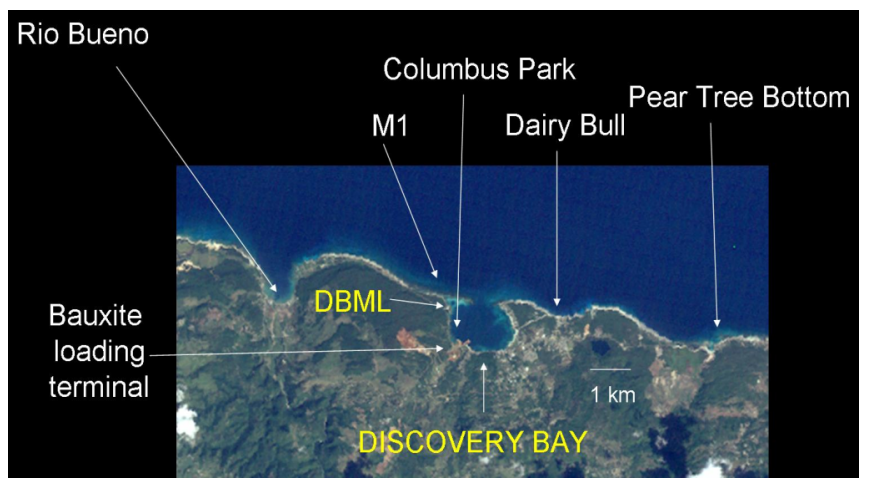

Fig. (1). Satellite image of the coral reef study sites around Discovery Bay on the North coast of Jamaica. DBML, Discovery Bay Marine Laboratory. The Bauxite loading terminal for ships is located in Discovery Bay.

\section{RESULTS}

Macroalgae (notably Lobophora and Dictyota species) were dominant (c. $80 \%$ cover) along the transects at M1 and Rio Bueno, whilst being almost absent $(<1 \%$ cover) at Dairy Bull (Fig. 2a-c). From 2002 to 2003, there were no significant changes in the numbers or species of corals recorded along the transects, with the singular exception of an increase in Agaricia agaricites numbers at M1 (Fig. 3a-c). Macroalgal cover was insignificant along the transects in Columbus Park and Pear Tree Bottom. Radial growth rates of non-branching coral colonies are shown in Fig. (4) for the three sites. For colonies of Montastrea annularis, Porites astreoides, and Sidastrea siderea, radial growth rates were significantly $(\mathrm{p}<0.02)$ higher at Dairy Bull than at either M1 or Rio Bueno. For colonies of Colpophyllia natans and Montastrea fankseii, radial growth rates were significantly $(\mathrm{p}<0.02)$ higher at Dairy Bull than at Rio Bueno. Only in the 


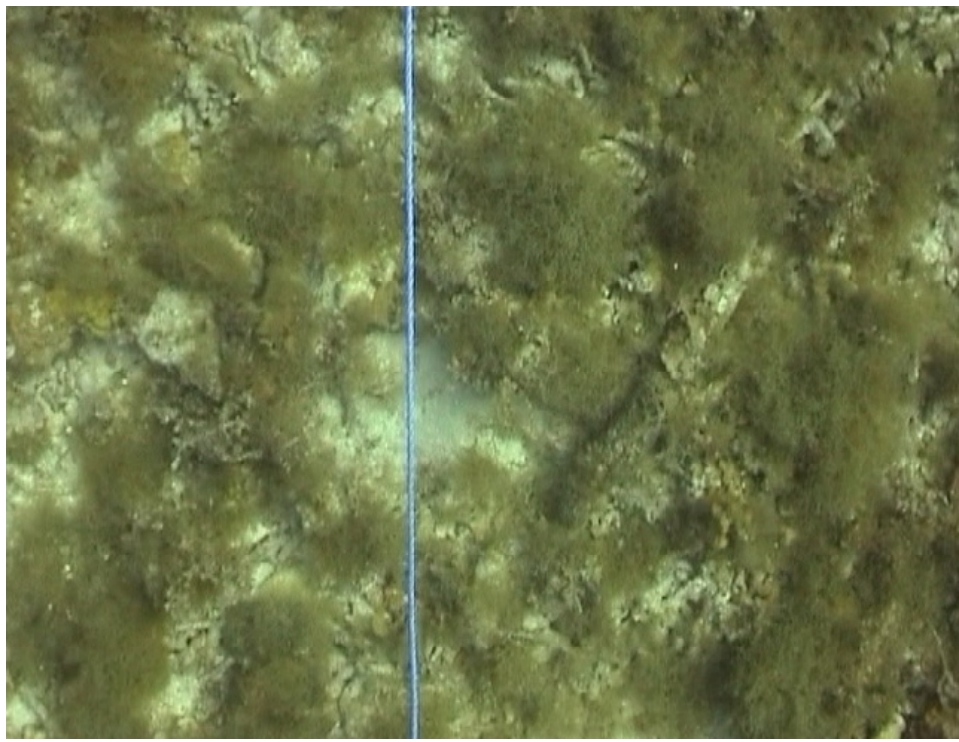

Fig. (2a). Macroalgal cover along one of the transects at M1.

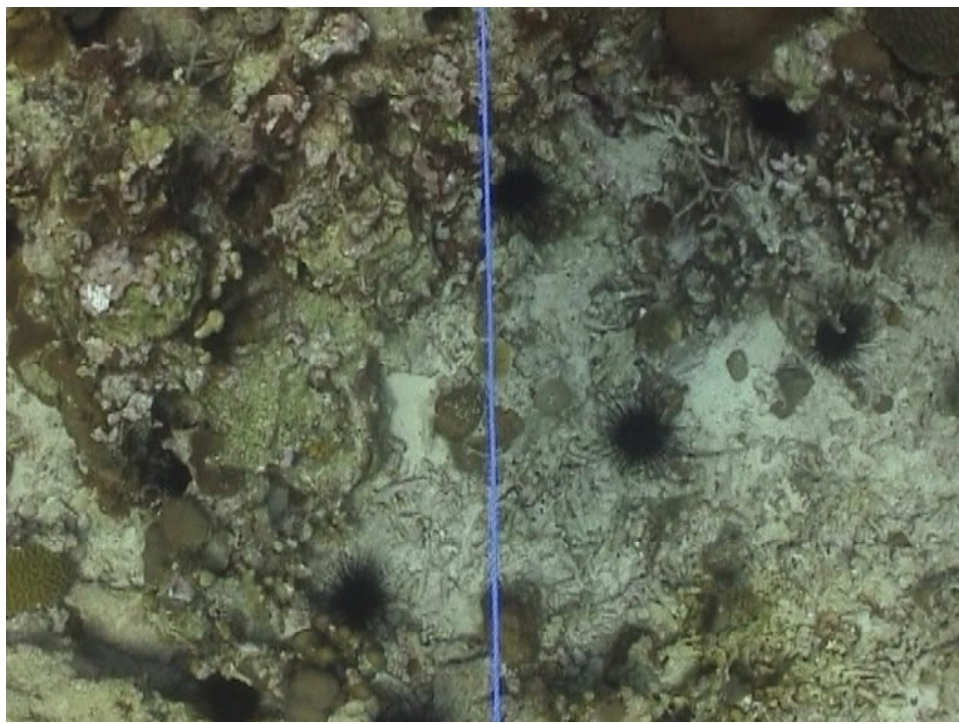

Fig. (2b). Absence of macroalgal cover along one of the transects at Dairy Bull.

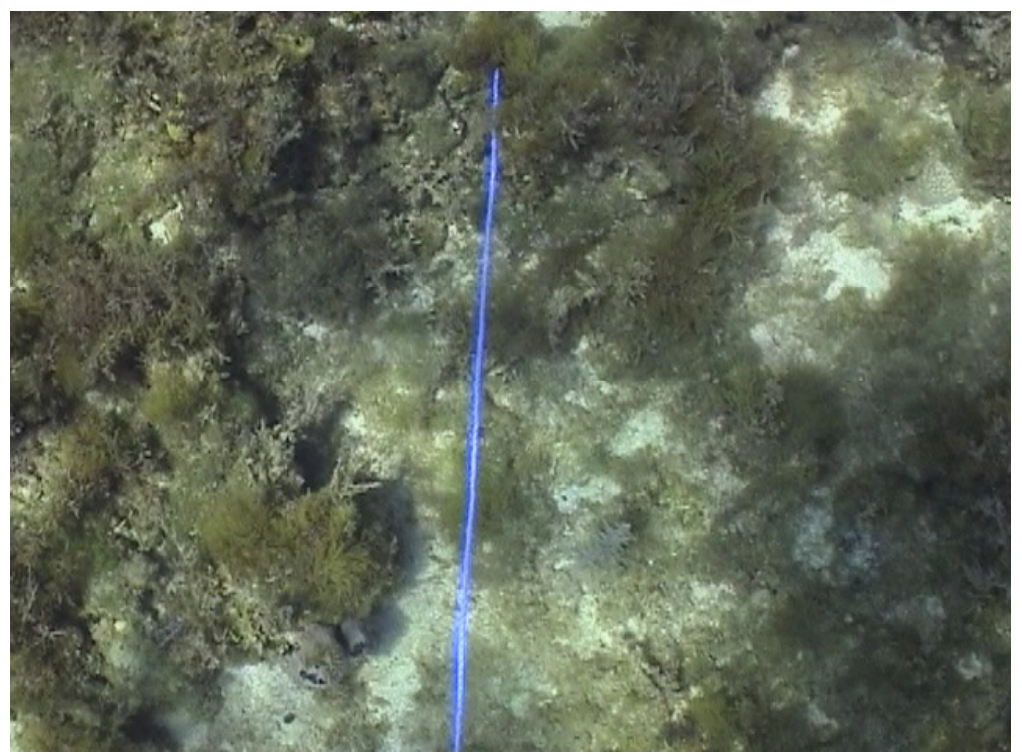

Fig. (2c). Macroalgal cover along one of the transects at Rio Bueno. 


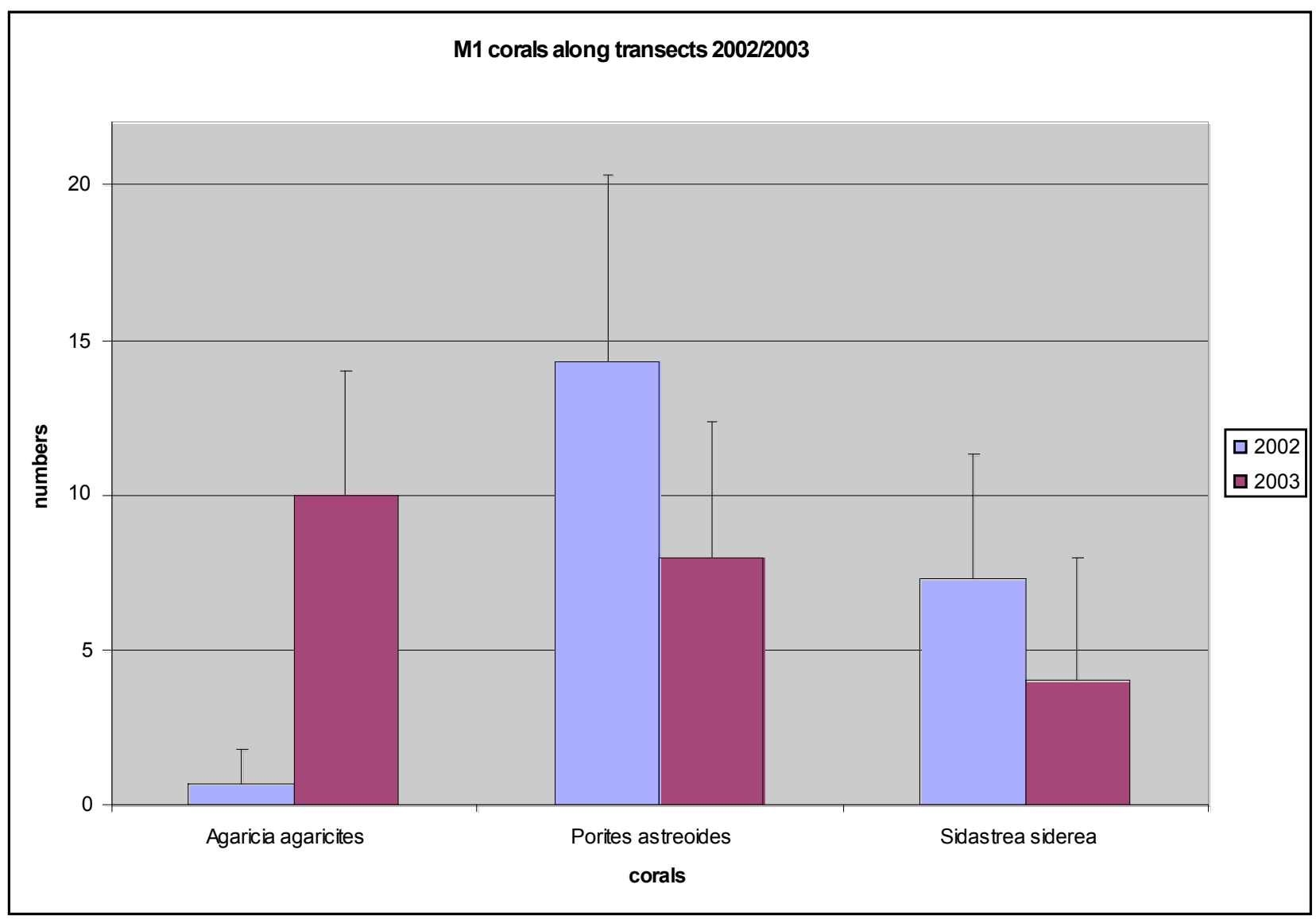

Fig. (3a). Numbers of Agaricia agaricites, Porites astreoides and Sidastrea siderea corals (mean \pm s.d. of data) along the transects at M1.

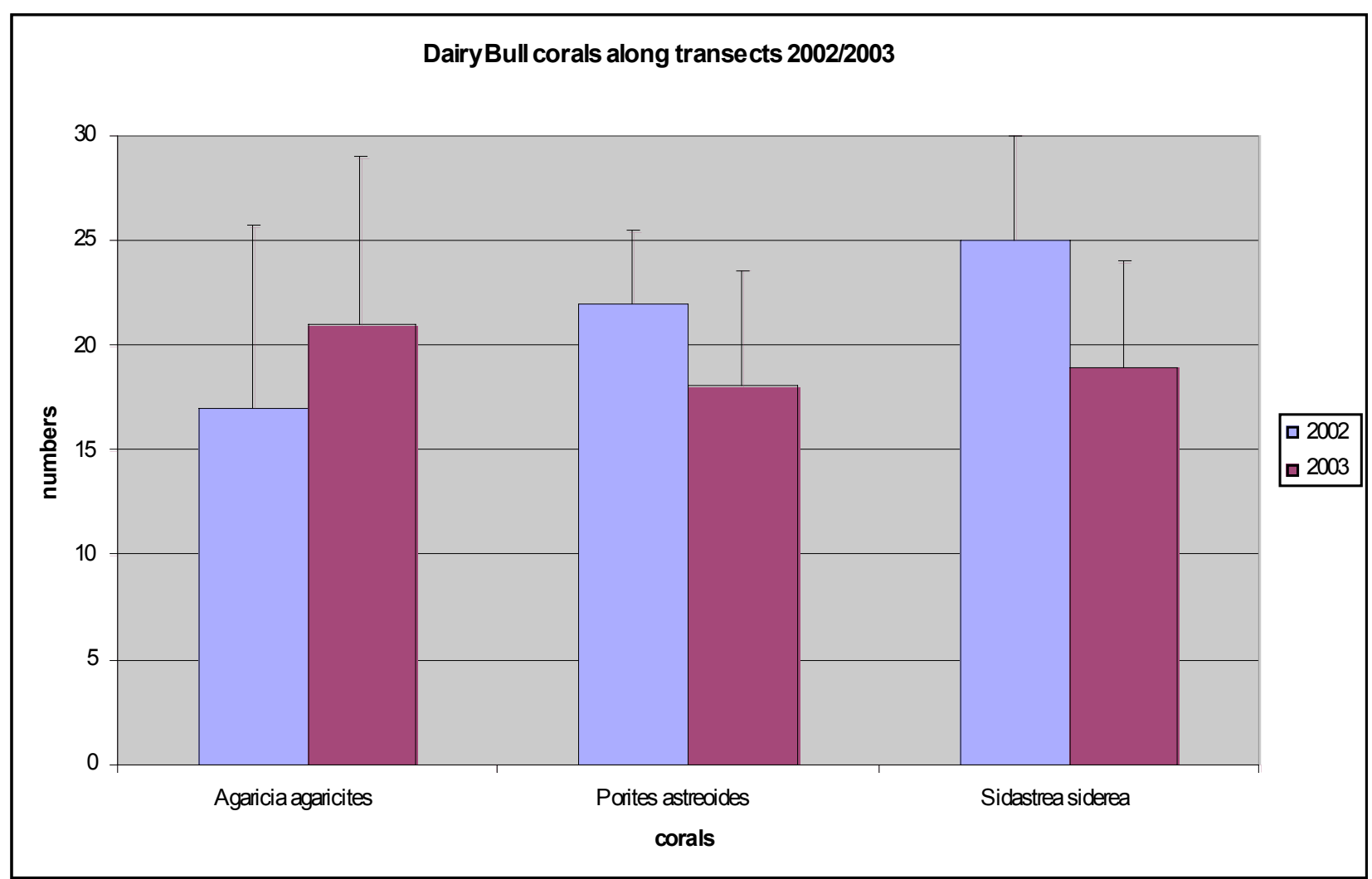

Fig. (3b). Numbers of Agaricia agaricites, Porites astreoides and Sidastrea siderea corals (mean \pm s.d. of data) along the transects at Dairy Bull. 


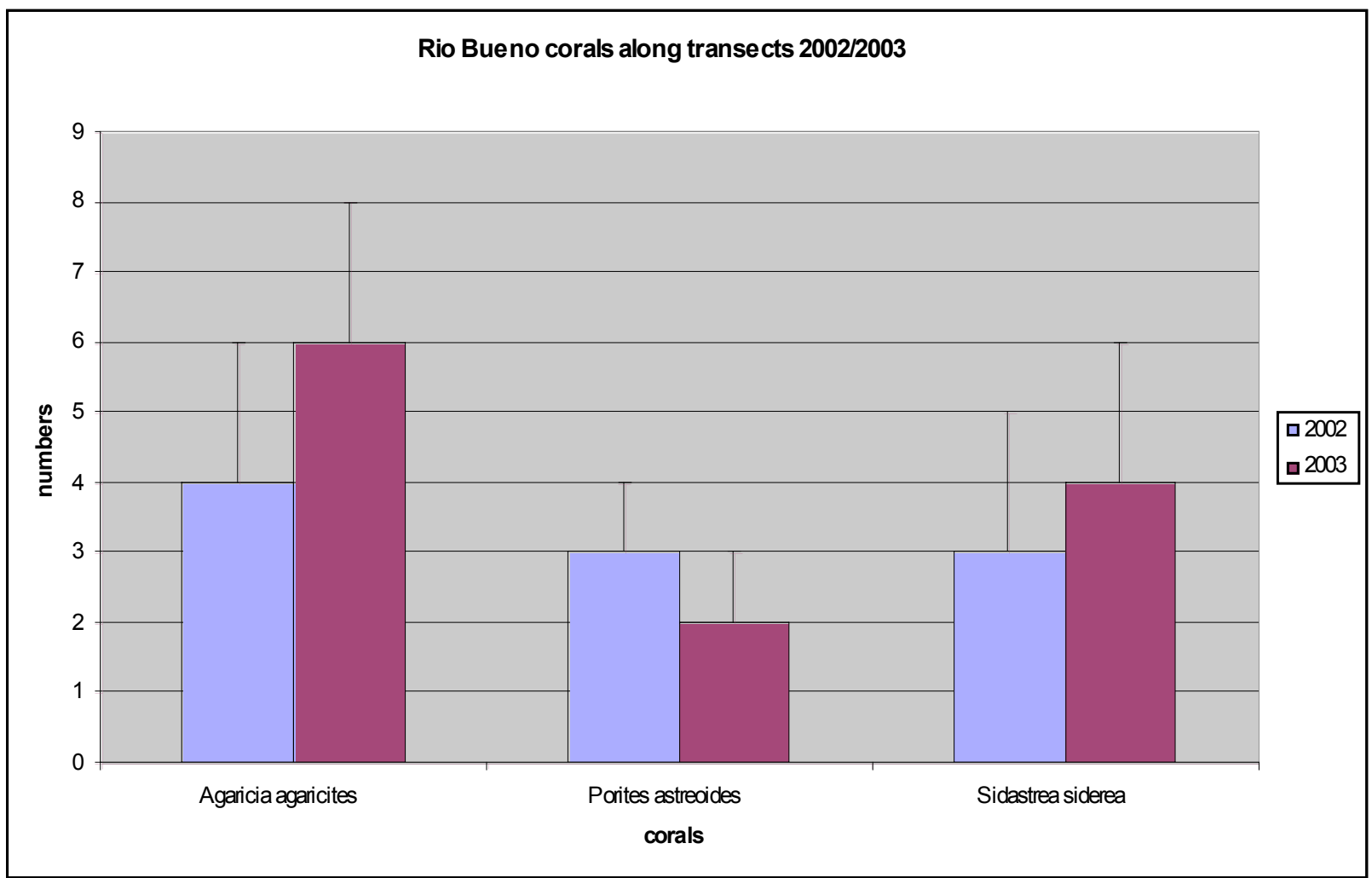

Fig. (3c). Numbers of Agaricia agaricites, Porites astreoides and Sidastrea siderea corals (mean \pm s.d. of data) along the transects at Rio Bueno.

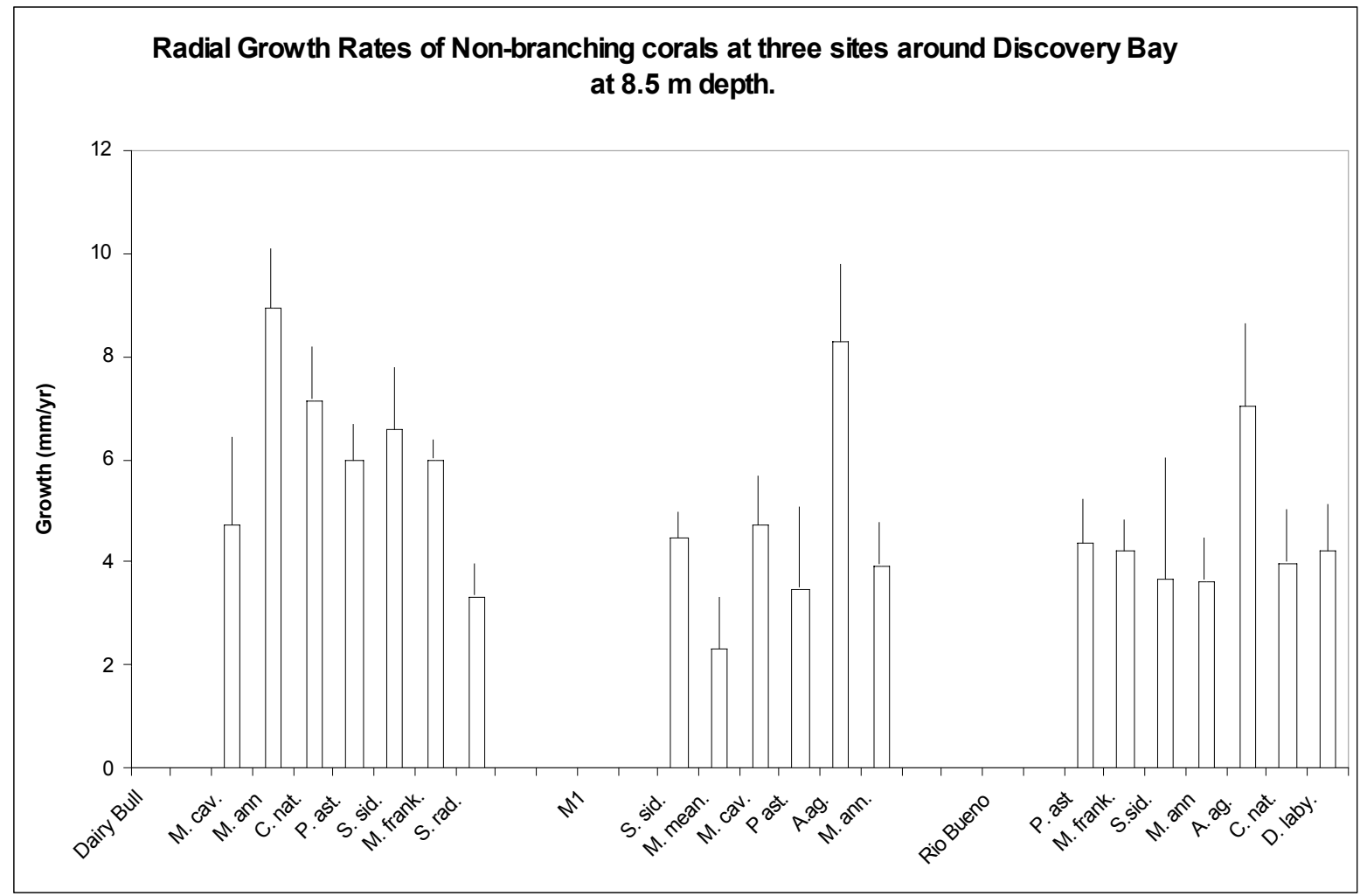

Fig. (4). Radial growth rates (mm/yr) of non-branching corals at Dairy Bull, M1 and Rio Bueno, at $8.5 \mathrm{~m}$ depth. Corals were: Montastrea cavernosa (M. cav); Montastrea annularis (M. ann); Colpophyllia natans (C. nat); Porites astreoides (P.ast); Sidastrea siderea (S. sid); Montastrea frankseii (M. frank); Siderastrea radians (S. rad); Meandrina meandrites (M. mean); Agaricia agaricites (A. ag); Diploria labyrinthiformis (D. laby). 


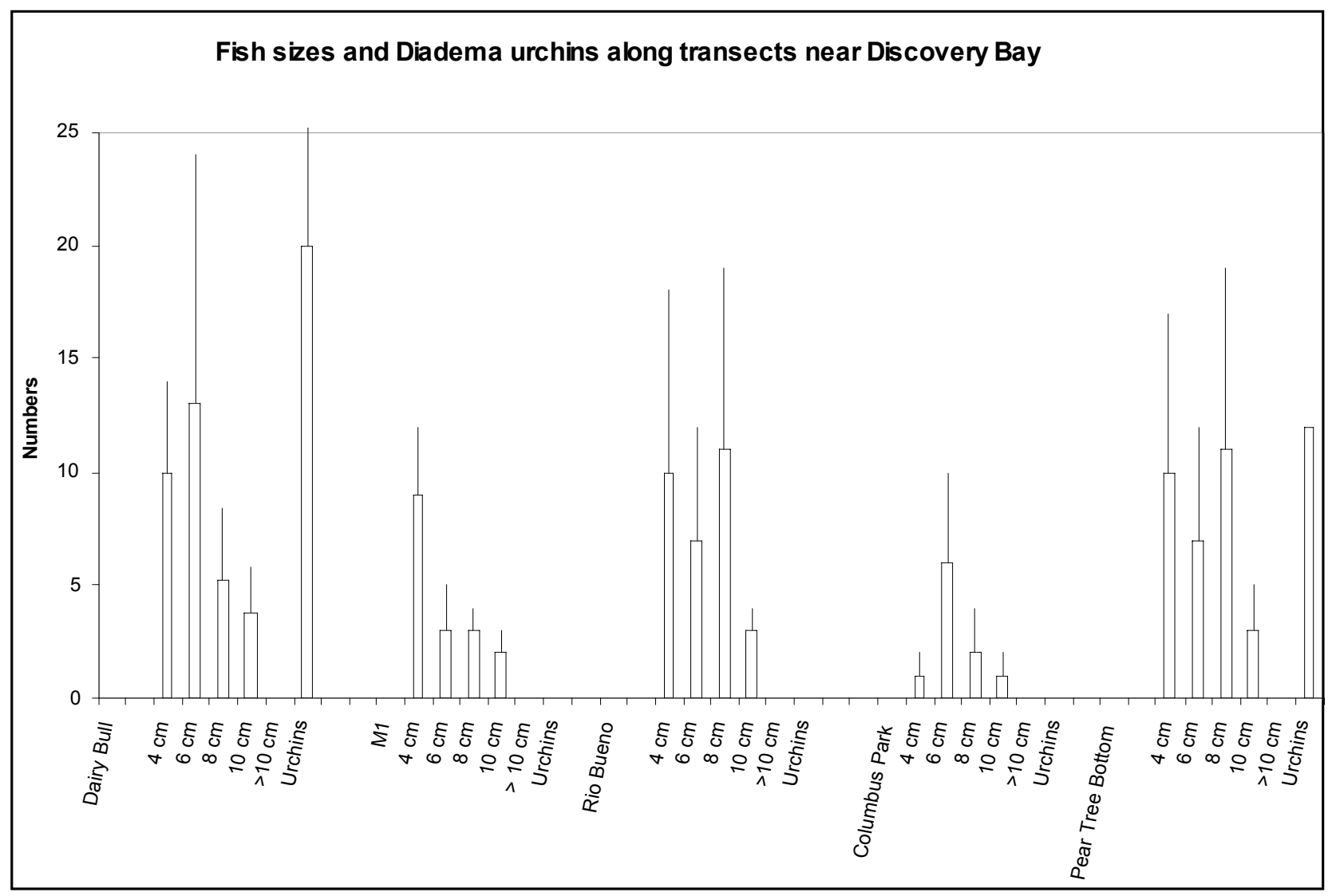

Fig. (5). Fish size and urchin (Diadema antillarum) number counts along transects at Dairy Bull, M1, Rio Bueno, Columbus Park, and Pear Tree Bottom. The y-axis refers to the mean abundance of fish and urchins along the $12 \mathrm{~m}$ transects, $2 \mathrm{~m}$ either side of the transect line, and, for fish, up to $4 \mathrm{~m}$ in height.

case of Montastrea cavernosa was there no significant difference in radial growth rates between the three sites.

The majority of fish at all sites studied were Pomacentridae (damselfishes and wrasses) and Scaridae (parrotfishes). While there were no significant differences in fish size counts over the sites studied, Dairy Bull showed by far the highest number of Diadema antillarum urchins, followed by Pear Tree Bottom (Fig. 5). There were no urchins along the transects at M1, Columbus Park or Rio Bueno.

\section{DISCUSSION}

There have been numerous studies on environmental and other parameters on the fringing reefs of Discovery Bay, Jamaica (see e.g. [11, 12]). Competition with algae can play a significant role in structuring coral communities [13] and in extreme cases can lead to significant decline [14]. While fish of the genus Scaridae are important for algal predation $[3,4]$, they can also be detrimental to corals [15]. In this study the Scarids were generally small at $<8 \mathrm{~cm}$ in length, with overfishing limiting their beneficial effect on the reef, as elsewhere in the Caribbean [16]. It has been suggested that macroalgal shading as well as contact is a significant inhibitor of coral growth, and our results are in accord with that hypothesis. Indeed, only Montastrea cavernosa colonies showed no significant difference in radial growth rates where there was high macroalgal cover. This may have been because the Montastrea cavernosa colonies were generally tall, with the majority of coralites well above the macroalgal cover. The fringing reefs of Discovery Bay are prey to both chronic and acute disturbances [17], as elsewhere in the Caribbean $[18,19]$. The major macroalgal grazer was Diadema antillarum, and that species had removed all macroalgae from our transect sites at Dairy Bull, allowing coral growth at rates higher than those at other sites where there was greater macroalgal cover. These studies suggest that marine park managers should foster macroalgal predation wherever possible, in order to limit the irreversible decline of coral reefs.

\section{ACKNOWLEDGEMENTS}

I thank the Earthwatch Institute and the Royal Society for funding, Dr. D.B. Lloyd for expert assistance with fish counts, Mr. Anthony Downes, colleagues and numerous volunteers at the Discovery Bay Marine Laboratory for help with data collection, and the two anonymous referees for suggesting improvements to the manuscript.

\section{REFERENCES}

[1] Crabbe MJC. Climate change and coral reefs. Biologist 2007; 54: 24-27.

[2] Crabbe MJC, Walker ELL, Stephenson DB. The impact of weather and climate extremes on coral growth. In: H. Diaz \& R. Murnane Eds. Climate Extremes and Society. Cambridge University Press. 2008; In press.

[3] Mumby PJ, Hastings A, Edwards HJ. Thresholds and the resilience of Caribbean coral reefs. Nature 2007; 450: 98-101. 
[4] Bythell JC, Hillis-Star ZM, Rogers CS. Local variability but landscape stability in coral reef communities following repeated hurricane impacts. Mar Ecol Prog Ser 2000; 204: 93-100.

[5] Box SJ, Mumby PJ. Effect of macroalgal competition on growth and survival of juvenile Caribbean corals. Mar Ecol Prog Ser 2007; 342: 139-149.

[6] Lirman D. Competition between macroalgae and corals:effects of herbivore exclusion and increased algal biomass on coral survivorship and growth. Coral Reefs 2001; 19(2): 392-399.

[7] Crabbe MJC, Karaviotis S, Smith DJ. Preliminary comparison of three coral reef sites in the Wakatobi Marine National Park (S.E. Sulawesi, Indonesia): Estimated recruitment dates compared with Discovery Bay, Jamaica. Bull Mar Sci 2004; 74(2): 469-476.

[8] Crabbe MJC, Smith DJ. Sediment impacts on growth rates of Acropora and Porites corals from fringing reefs of Sulawesi, Indonesia. Coral Reefs 2005; 24: 437-441.

[9] Crabbe MJC. Global warming and coral reefs:Modelling the effect of temperature on Acropora palmata colony growth. Comp Biol Chem 2007; 31: 294-297.

[10] Crabbe MJC, Smith DJ. Computer modeling and estimation of recruitment patterns of non-branching coral colonies at three sites in the Wakatobi Marine Park, S.E. Sulawesi, Indonesia; implications for coral reef conservation. Comp Biol Chem 2003; 27: 1727.
[11] Mallela J, Perry CT. Calcium carbonate budgets for two coral reefs affected by different terrestrial runoff regimes, Rio Bueno, Jamaica. Coral Reefs 2007; 26(1): 129-145.

[12] Greenaway AM, Gordon-Smith DA. Limnol Oceanog 2006; 51(5): 2206-2220.

[13] Nugues MM, Bak RPM. Differential competitive abilities between Caribbean coral species and a brown algaa: a year of experiments and a long-term perspective. Mar Ecol Prog Ser 2006; 315: 75-86.

[14] Rogers CS, Miller J. Permanent 'phase shifts' or reversible declines in coral cover? Lack of recovery of two coral reefs in St. John, US Virgin Islands. Mar Ecol Prog Ser 2006; 306: 103-114.

[15] Miller MW, Hay ME. Effects of fish predation and seaweed competition on the survival and growth of corals. Oecologia 1998; 113(2): 231-238.

[16] Hawkins JP, Roberts CM. Effects of artisanal fishing on Caribbean coral reefs. Conserv Biol 2004; 18(1): 215-226.

[17] Crabbe MJC, Carlin JP. Industrial sedimentation lowers coral growth rates in a turbid lagoon environment, Discovery Bay, Jamaica. Int J Integr Biol 2007; 1: 37-40.

[18] Crabbe MJC, Martinez E, Garcia C, et al. Growth modeling indicates hurricanes and severe storms are linked to low coral recruitment in the Caribbean. Mar Environ Res 2007; doi: 10.1016/j.marenvres.2007.11.006.

[19] Mumby PJ, Foster NL, Fahy EAG. Patch dynamics of coral reef macroalgae under chronic and acute disturbance. Coral Reefs 2005; 24(4): 681-692. 